\title{
Spectrum of infections in physiotherapy and rehabilitation ward for war victims and veterans from Iraq and Syria (short note)
}

I. Khaled (Ibrahim Khaled)2 , P. Ali Haij (Peri Ali Haji) $)^{1,2,3}$, V. Krcmery (Vladimir

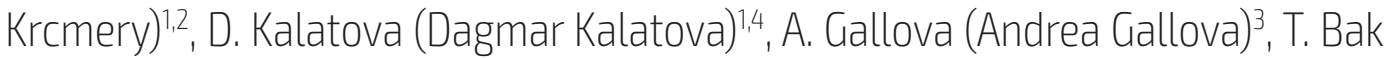
(Tadeusz Bak)3 ${ }^{3}$ I. Schumann (Ingrid Schumann) ${ }^{3}$, Z. Dudova (Zuzana Dudova) 1,2, K. Zoller (Katarina Zoller) 1,2,3, B. Reith (Bruce Reith)3, M. Obtulovic (Miroslav Obtulovic) ${ }^{3}$, M. Olah (Michal Olah) ${ }^{3,6}$, T. Hrindova (Tatiana Hrindova) ${ }^{3}$, M. Belovicova $(\text { Maria Belovicova) })^{3}$

Original Article

${ }^{1}$ UNHCR Refugee camp Veria, Greece

${ }^{2}$ UNHCR Refugee camp, Alexandria, Greece

${ }^{3} \mathrm{PhD}$ and MSc program of St. Elisabeth University, Slovakia

${ }^{4}$ Jan Neumann Institute of St.Elisabeth University, Pribram, Czech Republic

${ }^{5}$ University Hospital Trencin, Slovakia

${ }^{6}$ University of Social and Administrative Affairs, Vitezslava Nezvala 801/1, 73601 Havirov, Czech Republic

\section{E-mail address:}

michalolah@gmail.com

\section{Reprint address:}

Michal Olah

St. Elisabeth University of Health and Social Sciences

Nam. 1. Maja 1

Bratislava, Slovakia

Suource: Clinical Social Work and Health Intervention Pages: $26-28$

Volume: 8

Issue: 2

\section{Reviewers:}

Johnson Nzau Mavole

Catholic university of Eastern Africa, Nairobi, Kenya

Vitalis Okoth Odero

Catholic university of Eastern Africa, Nairobi, Kenya

\section{Key words:}

War victims, Infection, Rehabilitation, Iraq, Veterans. 


\section{Publisher:}

International Society of Applied Preventive Medicine i-gap

CSWHI 2017; 8(2): 26 - 28; DOI 10.22359/cswhi_8_2_05 @ 2017 Clinical Social Work and Health Intervention

\section{Abstract:}

Spectrum of infectious diseases in Physiotherapy and Rehabilitation Ward of Military Hospital in Iraq sponsored by the German Armed Forces is analyzed. In contrast to usual bacterial flora in non-war zones gram negative bacteria from external sources during blast injuries were found, including Acinetobacter baumanii, Pseudomonas putida, Enterobacteriaceae and Flavobacteria.

\section{Conflict of interest:}

The authors whose names are listed in the title of the article certify that they have NO affiliations with or involvement in any organization or entity with any financial interest (such as honoraria; educational grants; participation in speakers' bureaus; membership, employment, consultancies, or other equity interest), or non-financial interest (such as personal or professional relationships, affiliations, knowledge or beliefs) in the subject matter or materials discussed in this manuscript.

\section{Introduction}

Rehabilitation and physiotherapy wards for either civilian or veterans are integral parts of all field and military hospitals since war in Afghanistan in 2001and after that in all conflicts in Middle East (Iraq 2003, Lybia 2009, Syria 2011). (1-5) The aim of this study was to compare etiology of infections in patients recovering in this kind of wards for limb injuries or prosthesis after war related injuries in 2016-2017. (6-10) Other aim was to assess the proportion of MRSA versus other organisms among isolates in 2016-2017 in a Greek clinic for war victims from Syria and Iraq.

\section{Patients and methods}

In total, 197 patients were admitted for rehabilitation with new prosthesis received from international humanitarian organisations in 2016 in a Greek Military Facility in UNHCR camp Veria, Greece. Type of patient, injury and etiology of infection was recorded. Medical data were then compared and analysed. Among other data, sociodemographic data on post-war victims were collected as well.

\section{Results and discussion}

Majority of patients (167 out of 197) were victims of war injury - traumatic amputation of leg or arm with prosthesis replacement. Infections were mainly due to postoperative complications (wounds). Out of 167 traumatic limb amputations were 37 upper limb and 130 lower limb. Other 20 amputations were caused by infected burns or other causes (9). One patient was lost to follow-up. Post-operative wound infection was present in 130 cases, other 11 patients already came with infected injury. Skin and soft tissue infection not related to operation was present in 51 cases. Healthcare infrastructure after exodus in 2015/2016 in all Balkan countries 
is not sufficient to cover medical and social pathology (1-5). MRSA is usually referred as a commonest pathogen, following by non-fermenting GNB (6-10).

Table 1: Etiology of infections among197 war victims in field hospital in Iraq

\begin{tabular}{|l|c|}
\hline Non-fermenting GNB & 31 \\
\hline Pseudomonadacae (NonA) & 16 \\
\hline Acinetobacter spp. & 20 \\
\hline Enterobacteriaceae & 18 \\
\hline S. aureus & 15 \\
\hline S. pyogenes & 10 \\
\hline Other & 7 \\
\hline Unknown & 50 \\
\hline
\end{tabular}

\section{Conclusions}

Spectrum and etiology of inections in patients with war related traumatic injuries is different than in patients from EU. Instead of MRSA and S.pyogenes, Gram-negative bacteria, such as Pseudomonas species, Acinetobacter and Enterobacteriaceae are prevalent. Low prevalence of MRSA could be explained by extraordinary and different causes of injuries (post-war trauma and physiotherapy) in contrast to non-war related injuries (car accidents, sports, incidental injuries).

\section{References}

1. KIMULI D, MIKLOSKOVA M, SPANIK S, SUVADA J, ADAMCOVA J, TOMANEK P, KAFKOVA J, CZARNECKI P (2016). Social Pathology II. Warszaw, Management University, 2016. pp.: 455.

2. BUJDOVA N (2015). Development and legal regulation of voluntary actvities in Slovakia. Aspects of cross-border cooperation in the field of volunteering. Liraprint Ukrajina, 2015, 194 s. ISBN 978-617-596-219-0.

3. BUJDOVA N (2015). The elimination of problematic behavior of childen in relation to the State Family Policy. SPAY, Social Pathology Among Youth. St. Elisabeth
University of Health and Social Work Bratislava. 2015 s. 93. ISBN 978-80-8132131-3.

4. POLONOVAJ(2015). Respiratory infections after camping in free nature are the current diseases in Migrants to Austria and Germany via Hungary in September 2015: Experience from Roszke and Vamoszabadi. In Krcmery V, Liskova A, Mrazova M, Herdics G, Khali I, Polonova J, Suvada J, Bucko L, Bibza M, Ondova P, Hajj P, Fer I. Clinical Social Work, 2015; 5(2 2015) 33-35. ISSN:2222-386X.

5. POLONOVA J (2015). Self-acceptance, self-esteem building and experiencing of healthy sexuality among youth as the prevention of an abuse in partnerships In Suvada J - Tomanek P (eds.), 2015. Social pathology among youth (abstract book). Bratislava: St. Elisabeth University of Health and Social Work Bratislava, 2015. ISBN 978-80-8132-131-3. 73 - 74 p.

6. AEILTS GD, SAPICO FL, CANAWATH HN, MALIK GM, MONTGOMERIE JZ (1982). Methicillin-resistant Staphylococcus aureus colonization and infection in a rehabilitation facility. J Clin Microbiol. 1982, 16: 218-223.

7. HASSOUNA H, HAQ EU, GALL A (2008). MRSA colonisation in spinal cord injury: implications on patients rehabilitation. Acta Orthop Belg. 2008, 74: 528-530.

8. WEBBER KL, MACPHERSON S, MEAGHER A, HUTCHINSON S, LEWIS B (2012). The impact of strict isolation on MR$S A$ positive patients: an action-based study undertaken in a rehabilitation center. Rehabil Nurs. 2012, 37: 43-50. 10.1002/RNJ.00007.

9. VOVKO P, RETELJ M, CRETNIK TZ, JUTERSEK B, HARLANDER T, KOLMAN J, GUBINA M (2005). Risk factors for colonization with MRSA in a long-term care facility in Slovenia. Infect Control Hosp Epidemiol. 2005, 26: 191-195. 10.1086/502525.

10. THOMAS R (2013). MRSA in early rehabilitation - incidence, prevalence and morbidity. Neurol Rehabil. 2013, 19: 118-122. 